\title{
Agronomic performance of lettuce cultivars in different seasons and shading conditions
}

\author{
Rendimento agronómico de cultivares de lechuga \\ en diferentes estaciones y condiciones de sombra \\ Fernanda Carini ${ }^{1 *}$, Alberto Cargnelutti Filho ${ }^{2}$, Jéssica Andiara Kleinpaul ${ }^{1}$, \\ Ismael Mario Márcio Neu ${ }^{1}$, Daniela Lixinski Silveira ${ }^{1}$, Milena Pacheco ${ }^{3}$, Jerônimo Luiz Andriolo ${ }^{2}$
}

\begin{abstract}
The objectives of this study were to evaluate the agronomic performance of nine lettuce cultivars (Gloriosa, Pira Verde, Stella, Ceres, Grandes Lagos, Rubinella, Crocantela, Elisa and Vera), in three seasons (autumn-winter, spring and summer) and evaluate the effect of shade netting in spring and summer. Ten experiments were carried out, using the soilless cultivation systems in a sheltered environment. The experimental design was completely randomized, six benches were used in the autumn-winter season and four in both spring and summer, with 44 pots per bench. Lettuce seedlings were transplanted into 3-liter pots filled with sand. During the spring and summer seasons experiments were conducted with and without a $18 \%$ black shade netting placed $1.5 \mathrm{~m}$ above the plants. Nutritional supply was provided by nutrient solution recirculating in an automatically operated irrigation system. The evaluated traits were as follows: number of leaves, fresh and dry leaf matter, stem length, stem diameter, fresh and dry stem matter, fresh and dry shoot matter, root length and fresh and dry root matter. The cultivars Gloriosa (in autumn-winter), Grandes Lagos and Gloriosa (in the spring) and Crocantela and Vera (in the summer), presented greater matter yield and are deemed the most suitable for cultivation in these seasons. The use of a shade netting within the sheltered environment did not improve the performance of the cultivars and its use is not necessary in the spring and summer.
\end{abstract}

Keywords: Lactuca sativa L., growth, soilless cultivation, shade netting.

\section{RESUMEN}

El objetivo de este trabajo fue evaluar agronómicamente nueve cultivares de lechuga (Gloriosa, Pira Verde, Stella, Ceres, Grandes Lagos, Rubinella, Crocantela, Elisa y Vera), en tres estaciones del año (otoño-invierno, primavera y verano), y el efecto de la malla de sombreado en los períodos de primavera y verano. Se realizaron diez experimentos, utilizando la técnica de cultivo sin suelo, en ambiente protegido. Se empleó un diseño experimental completamente al azar, en seis mesas en la temporada de otoño-invierno y cuatro en primavera y verano, con 44 macetas por mesa. Cada maceta tenía una capacidad de 3 L, y fueron llenadas con arena para el posterior trasplante de los plantines de lechuga. En la primavera y el verano se realizaron experimentos con y sin malla de sombreo. La malla utilizada fue de color negro, con un $18 \%$ de sombra, a 1,5 m sobre el cultivo. El suministro nutricional se se hizo por medio de una disolución nutritiva en sistema de fertirriego recirculante automático. Los parámetros evaluados fueron número de hojas, peso de materia fresca y seca de hojas, longitud del tallo, diámetro del tallo, peso de materia fresca y seca del tallo, peso de materia fresca y seca de parte aérea, longitud de raíces y peso de materia fresca y seca de raíces. Los cultivares Gloriosa (en la estación otoño-invierno), Grandes Lagos y Gloriosa (en la estación primavera) y Crocantela y Vera (en la estación verano) presentaron la mayor producción y son los más indicados para el cultivo en esas estaciones. La malla de sombreo en el interior del ambiente protegido no ha mejorado el rendimiento de los cultivares y su uso no es necesario en primavera y verano.

Palabras Claves: Lactuca sativa L., crecimiento, cultivo sin suelo, malla de sombreado.

\section{Introduction}

Lettuce (Lactuca sativa $L$.) is a species belonging to the Asteraceae family, originated in ancient Egypt, characterized as herbaceous plants with soft green stems, to which are attached smooth or curly leaves, which may or may not be arranged in a dense rosette which ultimately develops into a compact "head" (Ryder, 2002; Sala and Costa, 2012). The aerial part of the lettuce is produced

\footnotetext{
Programa de Pós-Graduação em Agronomia, Universidade Federal de Santa Maria. Santa Maria, RS, Brasil.

Departamento de Fitotecnia, Centro de Ciências Rurais, Universidade Federal de Santa Maria. Santa Maria, RS, Brasil.

Universidade Federal de Santa Maria. Santa Maria, RS, Brasil

* Correspondence author: carini.fc@gmail.com
}

Fecha de Recepción: 3 de Noviembre, 2018.

Fecha de Aceptación: 8 de Junio, 2019. 
and consumed, especially in Asia, Europe and the Americas (Lebeda et al., 2009). Annually Brazil produces about 14 million plants (Santos et al., 2015). It stands out as the most produced leafy vegetable in Brazil, due to low production costs and successive crops viable within the same year (Sala and Costa, 2012). Lettuce is popular vegetable among small farmers, which gives it great economic and social importance.

Lettuce cultivars are classified into groups according to their morphological characteristics. According to the Company of Warehouses of São Paulo (CEAGESP), $43.3 \%$ of consumers prefer crisphead lettuce (consistent loose leaves that do not form head), $41.2 \%$ iceberg lettuce (large solid hearts and delicate crispy leaves and loose heads), $5.0 \%$ the butterhead lettuce (smooth, delicate leaves and with loose head), $5.9 \%$ the mimosas (yellowish green leaves, with peaked edges, do not form head), $1.0 \%$ romaine (cone-like with an elongated firm head) and 3.6\% other variations (CEAGESP, 2016).

Lettuce is a temperate climate crop, with optimal growth and development with temperatures between $15.5^{\circ} \mathrm{C}$ and $18.3^{\circ} \mathrm{C}$ and with lower and higher limits of $7.2^{\circ} \mathrm{C} 23.9^{\circ} \mathrm{C}$, respectively (Maynard and Hochmuth, 2007). Temperatures above $30.0^{\circ} \mathrm{C}$, during the vegetative phase, accelerates the photosynthetic processes, reduces the amount of sugars and favors the development of floral stem (Filgueira, 2008; FAO, 2013). In a sheltered environment, high summer and spring temperatures hinder quality palatability in lettuce leaves. Another limiting factor to crop growth is the excess radiant energy that predisposes plants to photoinhibition, thermal stress and stomatal closure, thus reducing liquid photosynthesis (Fu et al., 2012; Ntsoane et al., 2016).

In Rio Grande do Sul, southern Brazil, the average temperature ranges from -3 to $18{ }^{\circ} \mathrm{C}$ in the coldest months (June, July and August) and above $22^{\circ} \mathrm{C}$ in the warmest months (December, January, February and March) (Alvares et al., 2013). The central region of Rio Grande do Sul is presents some of the highest temperatures in the state during the summer, due to its continental and low altitude. From April to September, this region is often subjected to weak to moderate frost (Heldwein et al., 2009).

The difference between the meteorological requirements of the lettuce crop and the available climatic conditions is the reason cultivars should be selected according to their requirements. However, cultivars indicated for a given season may have different behaviors, since lettuce cultivars present limited performance when submitted to high temperatures and solar radiation (Ntsoane et al., 2016). These factors influence the development and quality of the leaves.

Uno et al. (2016), in Japan, carried out studies with four lettuce cultivars (Hollywood, Frillice, Cesper and Mariano) investigating susceptibility to tip burn, one of the major physiological disorders due to elevated temperatures and calcium translocation deficiency. In Brazil, the studies are regionalized, and concentrate mainly on aspects related to productivity. In this context, Resende et al. (2017), evaluated six cultivars of in-soil grown crisphead lettuce for autumn-winter conditions in Petrolina, state of Pernambuco. In the same region and under similar cultivation conditions, Yuri et al. (2017) evaluated the performance of 22 iceberg lettuce genotypes. Performance of iceberg, butterhead and cirsphead cultivars for winter conditions in the town of Americana, state of São Paulo were studied by Prela-Pantano et al. (2015).

In the commercial lettuce farming, the management must be adapted in order to minimize the deficiencies or excesses related to the climatic conditions. In winter, cultivation in a sheltered environment can accumulate energy, increasing air temperature (Andriolo, 2017), which is beneficial for the development of plants. However, in the summer, if poorly managed or with insufficient ventilation the temperature may increase excessively. During summer in some periods of the day the maximum temperature can reach $40^{\circ} \mathrm{C}$, which is extremely harmful to the lettuce crop.

Shade netting has often been used as an alternative to modify the microclimate in vegetable crops. The moderate shade provided by black, red, blue, pearl and green netting aims to provide a favorable microclimate for crops (Costa et al., 2012, Shahak, 2014, Ilić and Fallik, 2017).

It is a general belief that different cultivars present distinct performance, within each growing season, and that in spring and summer the shade netting improves the agronomic performance of the cultivars. This study aimed to evaluate the agronomic performance of nine lettuce cultivars (Gloriosa, Pira Verde, Stella, Ceres, Grandes Lagos, Rubinella, Crocantela, Vera and Elisa) in three seasons (autumn-winter, spring and summer) and to infer about the effect of shade netting in spring and summer. 


\section{Material and Methods}

Ten experiments were carried out in the town of Santa Maria, Rio Grande do Sul (latitude 29.43'24'S, longitude $53^{\circ} 43^{\prime} 12^{\prime \prime} \mathrm{W}$ and $95 \mathrm{~m}$ altitude), in a sheltered $115 \mathrm{~m}^{2}(5 \times 23 \mathrm{~m})$ environment covered with $150 \mu \mathrm{m}$ anti-UV polyethylene (Table 1). The crops were gown during the autumn-winter, spring and summer seasons, in 2016, 2017 and 2018. The region is humid subtropical Cfa type, as classified by Köppen, with hot summers and no dry season (Alvares et al., 2013).

Table 1. Dates of sowing, emergence, transplanting and harvesting of lettuce cultivars, evaluated in experiments and seasons autumn-winter, spring and summer, in two years, without e with shade netting and number of replicates (r).

\begin{tabular}{|c|c|c|c|c|c|c|c|c|c|}
\hline Experiments & Season & Year & Netting & Cultivars & Sowing & Emergence & Transplanting & Harvesting & $\mathrm{r}$ \\
\hline \multirow{3}{*}{1} & \multirow{3}{*}{ autumn-winter } & \multirow{3}{*}{2016} & \multirow{3}{*}{ without } & Gloriosa & 29-Apr-2016 & 4-May-2016 & 10-Jun-2016 & 11-Aug-2016 & 12 \\
\hline & & & & Pira Verde & 29-Apr-2016 & 4-May-2016 & 10-Jun-2016 & 28-Jul-2016 & 12 \\
\hline & & & & Stella & 29-Apr-2016 & 4-May-2016 & 10-Jun-2016 & 28-Jul-2016 & 12 \\
\hline \multirow{3}{*}{2} & \multirow{3}{*}{ autumn-winter } & \multirow{3}{*}{2017} & \multirow{3}{*}{ without } & Gloriosa & 3-May-2017 & 8-May-2017 & 4-Jun-2017 & 20-Jul-2017 & 6 \\
\hline & & & & Pira Verde & 3-May-2017 & 8-May-2017 & 4-Jun-2017 & 13-Jul-2017 & 6 \\
\hline & & & & Stella & 3-May-2017 & 8-May-2017 & 4-Jun-2017 & 13-Jul-2017 & 6 \\
\hline \multirow{4}{*}{3} & \multirow{4}{*}{ spring } & \multirow{4}{*}{2016} & \multirow{4}{*}{ without } & Ceres & 13-Sep-2016 & 17-Sep-2016 & 14-Oct-2016 & 13-Nov-2016 & 4 \\
\hline & & & & Gloriosa & 13-Sep-2016 & 17-Sep-2016 & 14-Oct-2016 & 17-Nov-2016 & 4 \\
\hline & & & & Grandes Lagos & 13-Sep-2016 & 17-Sep-2016 & $14-O c t-2016$ & 17-Nov-2016 & 4 \\
\hline & & & & Rubinella & 13-Sep-2016 & 17-Sep-2016 & 14-Oct-2016 & 17-Nov-2016 & 4 \\
\hline \multirow{4}{*}{4} & \multirow{4}{*}{ spring } & \multirow{4}{*}{2017} & \multirow{4}{*}{ without } & Ceres & 13-Sep-2017 & 17-Sep-2017 & 19-Oct-2017 & 17-Nov-2017 & 4 \\
\hline & & & & Gloriosa & 13-Sep-2017 & 17-Sep-2017 & 19-Oct-2017 & 20-Nov-2017 & 4 \\
\hline & & & & Grandes Lagos & 13-Sep-2017 & 17-Sep-2017 & 19-Oct-2017 & 20-Nov-2017 & 4 \\
\hline & & & & Rubinella & 13-Sep-2017 & 17-Sep-2017 & 19-Oct-2017 & 17-Nov-2017 & 4 \\
\hline \multirow{4}{*}{5} & \multirow{4}{*}{ spring } & \multirow{4}{*}{2016} & \multirow{4}{*}{ with } & Ceres & 13-Sep-2016 & 17-Sep-2016 & 14-Oct-2016 & 13-Nov-2016 & 4 \\
\hline & & & & Gloriosa & 13-Sep-2016 & 17-Sep-2016 & $14-O c t-2016$ & 17-Nov-2016 & 4 \\
\hline & & & & Grandes Lagos & 13-Sep-2016 & 17-Sep-2016 & $14-O c t-2016$ & 17-Nov-2016 & 4 \\
\hline & & & & Rubinella & 13-Sep-2016 & 17-Sep-2016 & 14-Oct-2016 & 17-Nov-2016 & 4 \\
\hline \multirow{4}{*}{6} & \multirow{4}{*}{ spring } & \multirow{4}{*}{2017} & \multirow{4}{*}{ with } & Ceres & 13-Sep-2017 & 17-Sep-2017 & 19-Oct-2017 & 17-Nov-2017 & 4 \\
\hline & & & & Gloriosa & 13-Sep-2017 & 17-Sep-2017 & 19-Oct-2017 & 20-Nov-2017 & 4 \\
\hline & & & & Grandes Lagos & 13-Sep-2017 & 17-Sep-2017 & 19-Oct-2017 & 20-Nov-2017 & 4 \\
\hline & & & & Rubinella & 13-Sep-2017 & 17-Sep-2017 & 19-Oct-2017 & 17-Nov-2017 & 4 \\
\hline \multirow{4}{*}{7} & & & & Crocantela & 5-Jan-2017 & 8-Jan-2017 & 27-Jan-2017 & 20-Feb-2017 & 4 \\
\hline & & 2017 & without & Elisa & 5-Jan-2017 & 8-Jan-2017 & 27-Jan-2017 & 16-Feb-2017 & 4 \\
\hline & summer & 2017 & without & Rubinella & 5-Jan-2017 & 8-Jan-2017 & 27-Jan-2017 & 24-Feb-2017 & 4 \\
\hline & & & & Vera & 5-Jan-2017 & 8-Jan-2017 & 27-Jan-2017 & 20-Feb-2017 & 4 \\
\hline & & & & Crocantela & 8-Jan-2018 & 11-Jan-2018 & 9-Feb-2018 & 8-Mar-2018 & 4 \\
\hline 8 & summer & 2018 & without & Elisa & 8-Jan-2018 & 11-Jan-2018 & 9-Feb-2018 & 5-Mar-2018 & 4 \\
\hline 8 & summer & 2018 & without & Rubinella & 8-Jan-2018 & 11-Jan-2018 & 9-Feb-2018 & 8-Mar-2018 & 4 \\
\hline & & & & Vera & 8-Jan-2018 & 11-Jan-2018 & 9-Feb-2018 & 5-Mar-2018 & 4 \\
\hline & & & & Crocantela & 5-Jan-2017 & 8-Jan-2017 & 27-Jan-2017 & 20-Feb-2017 & 4 \\
\hline 9 & summer & 2017 & with & Elisa & 5-Jan-2017 & 8-Jan-2017 & 27-Jan-2017 & 16-Feb-2017 & 4 \\
\hline 9 & summer & 2017 & with & Rubinella & 5-Jan-2017 & 8-Jan-2017 & 27-Jan-2017 & $20-F e b-2017$ & 4 \\
\hline & & & & Vera & 5-Jan-2017 & 8-Jan-2017 & 27-Jan-2017 & 20-Feb-2017 & 4 \\
\hline & & & & Crocantela & 8-Jan-2018 & 11-Jan-2018 & 9-Feb-2018 & 8-Mar-2018 & 4 \\
\hline 10 & summer & 2018 & with & Elisa & 8-Jan-2018 & 11-Jan-2018 & 9-Feb-2018 & 5-Mar-2018 & 4 \\
\hline 10 & summer & 2018 & with & Rubinella & 8-Jan-2018 & 11-Jan-2018 & 9-Feb-2018 & 8-Mar-2018 & 4 \\
\hline & & & & Vera & 8-Jan-2018 & 11-Jan-2018 & 9-Feb-2018 & 5-Mar-2018 & 4 \\
\hline
\end{tabular}


Lettuce seedlings were produced in the floating system, with 200-cell expanded polystyrene trays, filled with commercial Plantmax ${ }^{\circledR}$ substrate. Either a pelletized seed or two non-pelleted seeds were placed in each cell. Thinning was performed between seven and nine days after the emergence. Transplant was performed when the plants presented four to five leaves. Sowing, emergence, transplanting and harvesting periods, as well as the number of replicates (plants) in each experiment are described in Table 1.

For the cultivation, six benches were used in the autumn-winter experiments and four in the spring and summer seasons. The benches were composed of a corrugated fibrocement tile, $3.66 \mathrm{~m}$ long, $1.10 \mathrm{~m}$ wide and $6 \mathrm{~mm}$ thick, with six $5-\mathrm{cm}$ deep channels. The channels were waterproofed with clear plastic $100 \mu \mathrm{m}$ film and filled with washed number two gravel. For the elevation $(0.85 \mathrm{~m})$ of the benches, masonry blocks were used in the initial and final portions, with $2 \%$ slope. This slope allowed the nutrient solution to return to the $500 \mathrm{~L}$ plastic storage tank. The solution was driven by a low-power submersible motor pump (driven by a timer) to a $25 \mathrm{~mm}$ PVC pipe. Four drip hoses derived from this pipe and each pot was placed under a dripper, maintaining a $30 \mathrm{~cm}$ distance between the plants in the row, with a density of 11.11 plants $\mathrm{m}^{-2}$. Each bench consisted of four rows, with 44 3-liter pots (11 pots per row), filled with sifted coarse sand, washed with electrical conductivity of zero $\mathrm{dS} \mathrm{m}^{-1}$. In the experiments with $18 \%$ shade netting, performed in the spring and summer seasons, the net was placed $1.5 \mathrm{~m}$ above the plants.

The nutrient solution with the following macronutrient composition (in mmol L-1) was used: 10.36 de $\mathrm{NO}_{3}^{-}, 1.0 \mathrm{H}_{2} \mathrm{PO}_{4}^{-} ; 3.36 \mathrm{NH}_{4}^{+} ; 1.0 \mathrm{SO}_{4}^{-}$, $4.0 \mathrm{~K}^{+} ; 2.0 \mathrm{Ca}^{2+} ; 1.0 \mathrm{Mg}^{2+}$; and micronutrients (mg L-1): $1.0 \mathrm{Fe}$; $0.50 \mathrm{Mn} ; 0.22$ of $\mathrm{Zn} ; 0.26$ of B; $0.06 \mathrm{Cu}$ and $0.03 \mathrm{Mo}$, for lettuce crops, with the electrical conductivity (EC) of $1.33 \mathrm{dS} \mathrm{m}^{-1}$ and $\mathrm{pH}$ ranging from 5.5 to 6.5 . $\mathrm{EC}$ and $\mathrm{pH}$ were monitored throughout the growing cycle and corrected when presenting a variation $20 \%$ higher or lower than the standard.

The treatments were cultivars at growing seasons, both with and without shade netting in spring and summer. Cultivars were used for each season, according to the technical recommendations of the companies which hold their registration. The cultivars evaluated - with the respective group in parentheses - in the autumn-winter season were: Gloriosa (iceberg), Pira Verde (green crisphead) e Stella (butterhead); in the spring: Ceres (green crisphead), Gloriosa (iceberg), Grandes Lagos (iceberg) e Rubinella (red crisphead); in summer: Crocantela (crisphead - iceberg), Elisa (butterhead), Rubinella (red crisphead) e Vera (green crisphead).

Evaluations were performed at harvest (Table 1). The criterion for defining the picking point of cultivars of the butterhead and crisphead types was when the abaxial leaves showed signs of senescence. For the iceberg cultivars, the compactness of the head was considered. The following traits were evaluated: number of leaves (NL), fresh leaf matter (FLM, in g plant $^{-1}$ ), stem length (SL, in $\mathrm{cm})$, stem diameter (SD, in $\mathrm{cm}$ ), fresh stem matter (FSM, in $\left.\mathrm{g} \mathrm{plant}^{-1}\right)$, root length (RL, in $\mathrm{cm}$ ) and fresh root matter (FRM, g plant ${ }^{-1}$ ). The samples were packed in a paper bag and placed into a forced hot air circulation oven $\left(60^{\circ} \pm 5^{\circ} \mathrm{C}\right)$ until constant matter of dry matter weight. The dry leaf matter (DLM, g plant ${ }^{-1}$ ), dry stem matter (DSM, $\mathrm{g}$ plant $\left.^{-1}\right)$ and dry root matter (DRM, g plant ${ }^{-1}$ ) were then weighed. The fresh matter of the aerial part $\left(\right.$ FMAP $=$ FLM + FSM, in g plant $\left.^{-1}\right)$ and dry matter of the aerial part $($ DMAP $=$ DLM+DSM, in $\mathrm{g}_{\text {plant }}{ }^{-1}$ ) were calculated.

The air temperature inside the growing environment was recorded by a digital data logger (resolution $0.1{ }^{\circ} \mathrm{C}$ and accuracy $0.5^{\circ} \mathrm{C}$ ), installed in a meteorological shelter. The solar radiation was registered in the automatic meteorological station, belonging to the 8th District of Meteorology - National Institute of Meteorology (INMET), located $300 \mathrm{~m}$ from the growing environment.

In each of the ten experiments, for each trait, the analysis of variance was performed via bootstrap with 10,000 resampling. Subsequently, the cultivar means were compared by the ScottKnott test via bootstrap with 10,000 resampling, with a 5\% significance. The analysis of variance and the Scott-Knott bootstrap tests were performed in the Sisvar software (Ferreira, 2014). According to Ferreira (2014), these statistical procedures are adequate to circumvent possible impacts of failure to meet the assumptions of normality of errors and homogeneity of residual variances. Statistical analyzes were performed using Microsoft Office Excel and the Sisvar software (Ferreira, 2014). 


\section{Results and Discussion}

In the experiments 1 and 2, performed in the autumn-winter season, without shade netting, the Gloriosa cultivar presented superior performance in all the traits, except for the number of leaves (NL), whereas the cultivar Stella presented higher NL. The cultivars Pira Verde and Stella presented inferior performance in relation to the Gloriosa cultivar, and similar to each other cultivars (Table 2). In experiment 1 , the Gloriosa cultivar presented fresh leaf matter of 266.58 g plant $^{-1}$ more than in experiment 2 . This difference can be attributed to the best meteorological conditions during the experiment 1 .
Whit minimum temperatures below $15^{\circ} \mathrm{C}$ and maximum temperatures under $30^{\circ} \mathrm{C}$ during most part of the cycle (Figure 1), which were close to those considered optimal for the growth and production of lettuce (Maynard and Hochmuth, 2007). In addition, the longer period between the transplant and the harvesting point in experiment 1 (62 days) compared to experiment 2 (46 days) may have contributed to the better performance of the plants in experiment 1 . The fresh matter of iceberg cultivars obtained by Yuri et al. (2017) and the fresh matter of iceberg, butterhead and crisphead cultivars obtained by Prela-Pantano et al. (2015), both in soil cultivation, were similar to those obtained in this study. Considering this,

Table 2. Number of leaves (NL), fresh matter (FLM, in g plant ${ }^{-1}$ ) and dry matter (DLM, g plant ${ }^{-1}$ ) leaves, stem length $(\mathrm{SL}$, in $\mathrm{cm})$, stem diameter (SD, in $\mathrm{cm})$, fresh stem matter (FSM, in g plant ${ }^{-1}$ ) and dry stem matter (DSM, in $\left.\mathrm{g} \mathrm{plant}^{-1}\right)$, fresh matter of the aerial part (FMAP, in in g plant $^{-1}$ ) and dry matter of the aerial part (DMAP, in $\mathrm{g} \mathrm{plant}^{-1}$ ), root length (RL, in cm), fresh root matter (FRM, g plant $\left.{ }^{-1}\right)$ and dry root matter (DRM, in $\mathrm{g} \mathrm{plant}^{-1}$ ) of three lettuce cultivars of (Gloriosa, Pira Verde e Stella), cultivated in the autumn-winter in 2016 and 2017.

\begin{tabular}{|c|c|c|c|c|c|c|}
\hline \multirow{2}{*}{ Cultivars } & \multicolumn{6}{|c|}{ Experiments 1 = season autumn-winter, year 2016, without shade netting } \\
\hline & NL & FLM & DLM & SL & $\mathrm{SD}$ & FSM \\
\hline Gloriosa & $25.08 \mathrm{~b}^{*}$ & $530.76 \mathrm{a}$ & $15.55 \mathrm{a}$ & $4.33 \mathrm{a}$ & $2.48 \mathrm{a}$ & $17.06 \mathrm{a}$ \\
\hline Pira Verde & $18.42 \mathrm{c}$ & $231.51 \mathrm{~b}$ & $11.14 \mathrm{~b}$ & $3.85 \mathrm{~b}$ & $2.08 \mathrm{~b}$ & $9.58 \mathrm{~b}$ \\
\hline Stella & $29.42 \mathrm{a}$ & $235.56 \mathrm{~b}$ & $10.02 \mathrm{~b}$ & $3.56 \mathrm{~b}$ & $2.08 \mathrm{~b}$ & $8.90 \mathrm{~b}$ \\
\hline Mean & 24.31 & 332.61 & 12.23 & 3.91 & 2.21 & 11.84 \\
\hline \multirow[t]{2}{*}{$\mathrm{CV}(\%)$} & 8.44 & 14.44 & 16.16 & 9.83 & 9.39 & 17.00 \\
\hline & DMS & FMAP & DMAP & RL & FRM & DRM \\
\hline Gloriosa & $1.06 \mathrm{a}$ & $547.81 \mathrm{a}$ & $16.61 \mathrm{a}$ & $35.63 \mathrm{a}$ & $20.14 \mathrm{a}$ & $1.98 \mathrm{a}$ \\
\hline Pira Verde & $0.60 \mathrm{~b}$ & $241.09 \mathrm{~b}$ & $11.73 \mathrm{~b}$ & $36.03 \mathrm{a}$ & $19.02 \mathrm{a}$ & $1.14 \mathrm{~b}$ \\
\hline Stella & $0.57 \mathrm{~b}$ & $244.45 \mathrm{~b}$ & $10.59 \mathrm{~b}$ & $27.52 \mathrm{~b}$ & $12.13 \mathrm{~b}$ & $1.21 \mathrm{~b}$ \\
\hline Mean & 0.74 & 344.45 & 12.98 & 33.06 & 17.09 & 1.44 \\
\hline \multirow[t]{3}{*}{$\mathrm{CV}(\%)$} & 22.56 & 14.38 & 16.21 & 13.28 & 28.50 & 27.65 \\
\hline & \multicolumn{6}{|c|}{ Experiments $2=$ season autumn-winter, year 2017, without shade netting } \\
\hline & NL & FLM & DLM & SL & SD & FSM \\
\hline Gloriosa & $18.00 \mathrm{~b}$ & $264.18 \mathrm{a}$ & $12.36 \mathrm{a}$ & $6.42 \mathrm{a}$ & $2.42 \mathrm{a}$ & $20.19 \mathrm{a}$ \\
\hline Pira Verde & $15.50 \mathrm{c}$ & $240.29 \mathrm{a}$ & $10.13 \mathrm{~b}$ & $2.72 \mathrm{~b}$ & $1.85 \mathrm{~b}$ & $5.49 \mathrm{~b}$ \\
\hline Stella & $24.33 \mathrm{a}$ & $215.79 \mathrm{a}$ & $8.50 \mathrm{~b}$ & $3.05 \mathrm{~b}$ & $1.93 \mathrm{~b}$ & $8.24 \mathrm{~b}$ \\
\hline Mean & 19.28 & 240.08 & 10.33 & 4.06 & 2.07 & 11.30 \\
\hline \multirow[t]{2}{*}{$\mathrm{CV}(\%)$} & 10.95 & 21.61 & 21.19 & 17.00 & 7.46 & 25.83 \\
\hline & DMS & FMAP & DMAP & RL & FRM & DRM \\
\hline Gloriosa & $0.96 \mathrm{a}$ & $284.37 \mathrm{a}$ & $13.33 \mathrm{a}$ & $23.47 \mathrm{a}$ & $23.13 \mathrm{a}$ & $1.36 \mathrm{a}$ \\
\hline Pira Verde & $0.27 \mathrm{~b}$ & $245.77 \mathrm{a}$ & $10.39 \mathrm{~b}$ & $24.25 \mathrm{a}$ & $18.43 \mathrm{a}$ & $1.02 \mathrm{a}$ \\
\hline Stella & $0.40 \mathrm{~b}$ & $224.03 \mathrm{a}$ & $8.90 \mathrm{~b}$ & $20.85 \mathrm{~b}$ & $17.92 \mathrm{a}$ & $1.18 \mathrm{a}$ \\
\hline Mean & 0.54 & 251.39 & 10.87 & 22.86 & 19.82 & 1.18 \\
\hline $\mathrm{CV}(\%)$ & 34.42 & 21.66 & 21.62 & 7.70 & 24.97 & 24.60 \\
\hline
\end{tabular}

* Means not followed by the same letters in the column (comparison of means between cultivars) differ to $5 \%$ of significance by the Scott-Knott test via bootstrap with 10,000 resampling. 


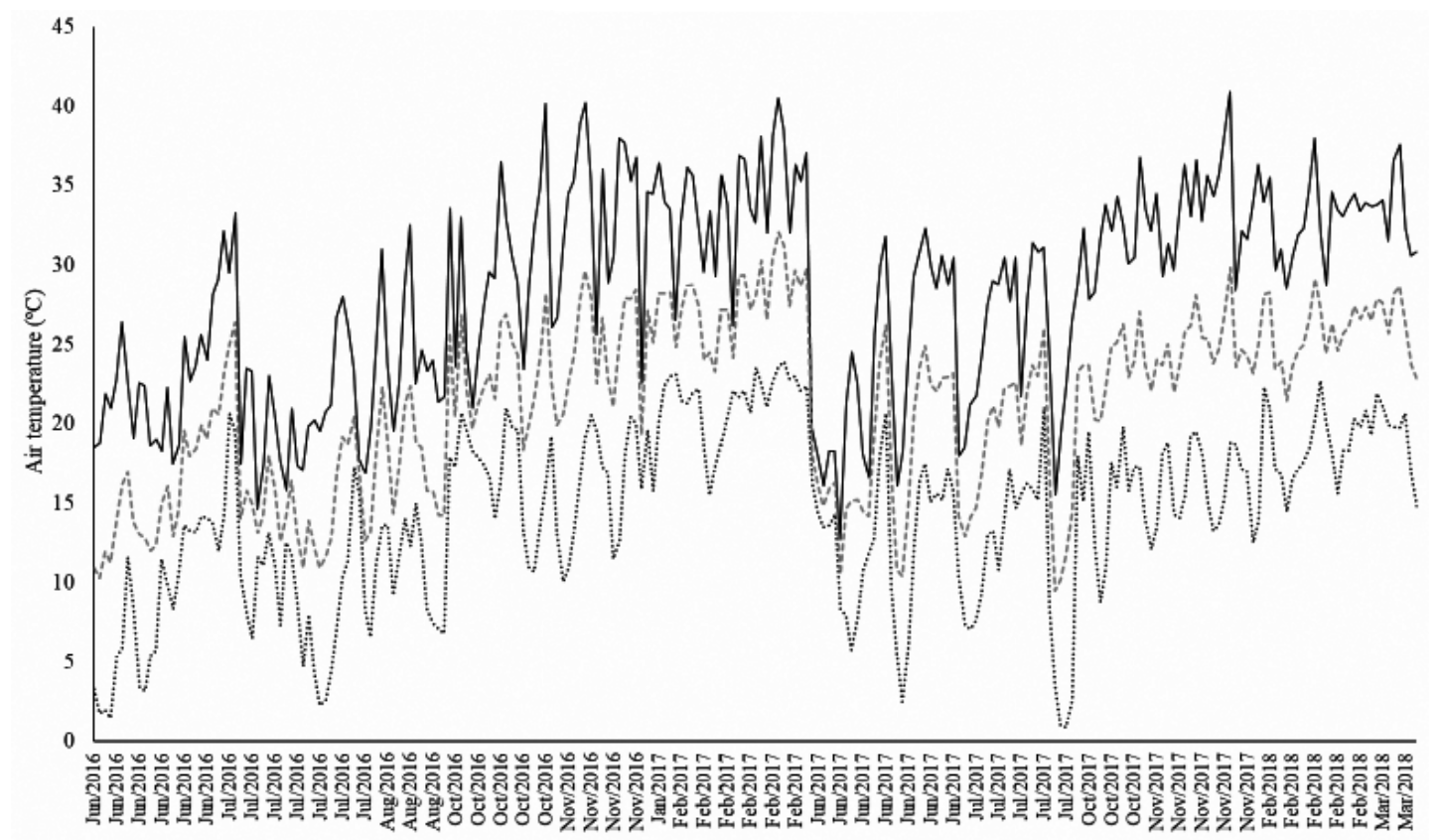

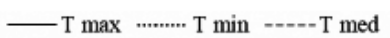

Figure 1. Maximum temperature ( $\mathrm{T}$ max), minimum temperature ( $\mathrm{T}$ min) and medium temperature ( $\mathrm{T}$ med) for the period from transplant to harvest, autumn-winter (June, July and August), spring (October and November) and summer (January, February and March), in Santa Maria, Rio Grande do Sul, Brazil.

even though there was a difference in performance between the experiments, Gloriosa showed better performance in both experiments. Thus, it can be inferred that this cultivar is the most suitable to be cultivated in the autumn-winter season.

In the spring, without shade netting (experiments 3 and 4), the cultivars had lower fresh and dry matter of the aerial part (FMAP and DMAP) in experiment 4 (Table 3), as a consequence of the maximum temperatures being higher than $30{ }^{\circ} \mathrm{C}$ practically during the entire production cycle (Figure 1). The cultivars Grandes Lagos and Gloriosa, respectively, presented superior performance in relation to the other cultivars for most traits (Table 3). Demonstrating greater plasticity in relation to the meteorological conditions and being better adapted to growing conditions in the spring. The cultivar Ceres showed intermediate and the cultivar Rubinella inferior performances. However, the performance of the Rubinella cultivar should be evaluated with caution, because the cultivars of the red crisphead segment present lower matter of the aerial part when compared to the iceberg cultivars. The results obtained in this study are consistent with those of Blat et al. (2011), which determined the fresh shoot matter for the cultivar Pira Roxa as 60.4 g plant $^{-1}$.

In the experiments carried out with shade netting, in the spring (experiments 5 and 6), the Grandes Lagos and Gloriosa cultivars presented similar results and superior performance for all the traits of experiment 5 (Table 4). In experiment 6 , the Grandes Lagos cultivar was superior in all the traits except number of leaves (NL) and root length (RL). However, the cultivars Ceres and Rubinella, in both experiments, presented similar inferior performance. In general, the behavior of the cultivars in the two experiments conducted without shade netting (experiments 3 and 4) and in the two experiments conducted with shade netting (experiments 5 and 6), was similar (Tables 3 and 4). Thus, it can be inferred that the cultivars Grandes Lagos and Gloriosa are the most suitable for cultivation in the spring and that the use of the $18 \%$ shade netting within a sheltered environment is not justified, since it did not reflect in better performance of cultivars.

In experiments $1,2,3,4,5$ and 6 the best cultivars were Grandes Lagos and Gloriosa, from 
Table 3. Number of leaves (NL), fresh matter (FLM, in $g$ plant ${ }^{-1}$ ) and dry matter (DLM, g plant ${ }^{-1}$ ) leaves, stem length $\left(\mathrm{SL}\right.$, in $\mathrm{cm}$ ), stem diameter (SD, in cm), fresh stem matter (FSM, in g plant ${ }^{-1}$ ) and dry stem matter (DSM, in $\mathrm{g} \mathrm{plant}^{-1}$ ), fresh matter of the aerial part (FMAP, in in $\mathrm{g} \mathrm{plant}^{-1}$ ) and dry matter of the aerial part (DMAP, in $\mathrm{g} \mathrm{plant}^{-1}$ ), root length

$(\mathrm{RL}$, in $\mathrm{cm})$, fresh root matter (FRM, g plant $\left.{ }^{-1}\right)$ and dry root matter (DRM, in g plant $\left.{ }^{-1}\right)$ of four lettuce cultivars of

(Ceres, Gloriosa, Grandes Lagos and Rubinella), cultivated in the spring in 2016 and 2017, without shade netting.

\begin{tabular}{|c|c|c|c|c|c|c|}
\hline \multirow{2}{*}{ Cultivars } & \multicolumn{6}{|c|}{ Experiments 3 = season spring, year 2016, without shade netting } \\
\hline & NL & FLM & DLM & SL & $\mathrm{SD}$ & FSM \\
\hline Ceres & $19.50 \mathrm{a}^{*}$ & $218.26 \mathrm{~b}$ & $11.91 \mathrm{~b}$ & $5.85 \mathrm{~b}$ & $2.38 \mathrm{a}$ & $17.23 \mathrm{~b}$ \\
\hline Gloriosa & $18.75 \mathrm{a}$ & $339.56 \mathrm{a}$ & $14.62 \mathrm{~b}$ & $5.18 \mathrm{~b}$ & $2.50 \mathrm{a}$ & $18.65 \mathrm{~b}$ \\
\hline Grandes Lagos & $18.75 \mathrm{a}$ & $348.62 \mathrm{a}$ & $19.46 \mathrm{a}$ & $6.98 \mathrm{a}$ & $2.58 \mathrm{a}$ & $28.44 \mathrm{a}$ \\
\hline Rubinella & $14.50 \mathrm{~b}$ & $121.59 \mathrm{c}$ & $5.69 \mathrm{c}$ & $5.93 \mathrm{~b}$ & $1.90 \mathrm{a}$ & $9.21 \mathrm{c}$ \\
\hline Mean & 17.88 & 257.01 & 12.92 & 5.98 & 2.34 & 18.38 \\
\hline \multirow[t]{2}{*}{$\mathrm{CV}(\%)$} & 11.13 & 8.09 & 16.43 & 14.05 & 17.36 & 16.84 \\
\hline & DMS & FMAP & DMAP & $\mathrm{RL}$ & FRM & DRM \\
\hline Ceres & $0.78 \mathrm{~b}$ & $235.49 \mathrm{~b}$ & $12.69 \mathrm{~b}$ & $19.83 \mathrm{~b}$ & $26.25 \mathrm{c}$ & $1.34 \mathrm{~b}$ \\
\hline Gloriosa & $0.73 \mathrm{~b}$ & $358.21 \mathrm{a}$ & $15.35 \mathrm{~b}$ & $23.98 \mathrm{a}$ & $33.13 \mathrm{~b}$ & $2.02 \mathrm{a}$ \\
\hline Grandes Lagos & $1.42 \mathrm{a}$ & $377.06 \mathrm{a}$ & $20.87 \mathrm{a}$ & $24.68 \mathrm{a}$ & $45.65 \mathrm{a}$ & $2.29 \mathrm{a}$ \\
\hline Rubinella & $0.35 \mathrm{c}$ & $130.79 \mathrm{c}$ & $6.03 \mathrm{c}$ & $21.45 \mathrm{~b}$ & $11.84 \mathrm{~d}$ & $0.77 \mathrm{c}$ \\
\hline Mean & 0.82 & 275.39 & 13.73 & 22.48 & 29.22 & 1.61 \\
\hline \multirow[t]{3}{*}{$\mathrm{CV}(\%)$} & 17.21 & 7.34 & 15.82 & 9.32 & 16.55 & 30.73 \\
\hline & \multicolumn{6}{|c|}{ Experiments 4 = season spring, year 2017, without shade netting } \\
\hline & NL & FLM & DLM & SL & $\mathrm{SD}$ & FSM \\
\hline Ceres & $15.25 \mathrm{~b}$ & $146.82 \mathrm{~b}$ & $7.83 \mathrm{~b}$ & $3.93 \mathrm{~b}$ & $1.88 \mathrm{~b}$ & $8.62 \mathrm{~b}$ \\
\hline Gloriosa & $21.50 \mathrm{a}$ & $267.00 \mathrm{a}$ & $11.95 \mathrm{a}$ & $3.58 \mathrm{~b}$ & $2.03 \mathrm{~b}$ & $8.32 \mathrm{~b}$ \\
\hline Grandes Lagos & $22.75 \mathrm{a}$ & $299.89 \mathrm{a}$ & $11.89 \mathrm{a}$ & $5.73 \mathrm{a}$ & $2.53 \mathrm{a}$ & $19.03 \mathrm{a}$ \\
\hline Rubinella & $14.75 \mathrm{~b}$ & $110.30 \mathrm{c}$ & $5.81 \mathrm{c}$ & $3.73 \mathrm{~b}$ & $1.50 \mathrm{c}$ & $5.35 \mathrm{c}$ \\
\hline Mean & 18.56 & 206.00 & 9.37 & 4.24 & 1.98 & 10.33 \\
\hline \multirow[t]{2}{*}{$\mathrm{CV}(\%)$} & 6.46 & 13.01 & 10.87 & 13.26 & 9.91 & 27.32 \\
\hline & DMS & FMAP & DMAP & $\mathrm{RL}$ & FRM & DRM \\
\hline Ceres & $0.46 \mathrm{~b}$ & $155.44 \mathrm{~b}$ & $8.29 \mathrm{~b}$ & $22.48 \mathrm{a}$ & $35.65 \mathrm{a}$ & $2.51 \mathrm{a}$ \\
\hline Gloriosa & $0.50 \mathrm{~b}$ & $275.32 \mathrm{a}$ & $12.45 \mathrm{a}$ & $23.48 \mathrm{a}$ & $37.17 \mathrm{a}$ & $2.46 \mathrm{a}$ \\
\hline Grandes Lagos & $1.06 \mathrm{a}$ & $318.92 \mathrm{a}$ & $12.94 \mathrm{a}$ & $22.53 \mathrm{a}$ & $42.16 \mathrm{a}$ & $3.41 \mathrm{a}$ \\
\hline Rubinella & $0.28 \mathrm{c}$ & $115.65 \mathrm{c}$ & $6.09 \mathrm{c}$ & $22.10 \mathrm{a}$ & $12.89 \mathrm{~b}$ & $1.16 \mathrm{~b}$ \\
\hline Mean & 0.57 & 216.33 & 9.94 & 22.64 & 31.96 & 2.38 \\
\hline $\mathrm{CV}(\%)$ & 33.04 & 13.16 & 11.41 & 12.85 & 13.00 & 32.84 \\
\hline
\end{tabular}

* Means not followed by the same letters in the column (comparison of means between cultivars) differ to $5 \%$ of significance by the Scott-Knott test via bootstrap with 10,000 resampling.

the iceberg cultivar group. The stem length of is related to bolting, which is not desired by either producers and consumers. The acceptable stem length for Iceberg cultivars varies from 6.0 to 9.0 $\mathrm{cm}$ (Yuri et al., 2017). In our experiments, the stem length of these two cultivars was within the quality standard, which reinforces the abovementioned inferences about the cultivars.

In the summer season, without shade netting (experiments 7 and 8), it was found that during experiment 7 , the maximum daily temperature was above $30{ }^{\circ} \mathrm{C}$ from transplant to harvest and reached a maximum of $40.5^{\circ} \mathrm{C}$ near the end of the cycle (Figure 1). With these conditions, the cultivar Vera presented superior performance in relation to the cultivars Rubinella, Crocantela and Elisa, respectively (Table 5). Excess temperature and solar radiation reduce photosynthesis and can cause damage to the photosynthetic apparatus (Taiz et al., 2017), reduces leaf matter and increases stem length, which are characteristics that anticipate harvesting. 
Table 4. Number of leaves (NL), fresh matter (FLM, in g plant ${ }^{-1}$ ) and dry matter (DLM, g plant ${ }^{-1}$ ) leaves, stem length $(\mathrm{SL}$, in $\mathrm{cm})$, stem diameter (SD, in $\mathrm{cm})$, fresh stem matter (FSM, in g plant ${ }^{-1}$ ) and dry stem matter (DSM, in $\mathrm{g} \mathrm{plant}^{-1}$ ), fresh matter of the aerial part (FMAP, in in $g_{\text {plant }}^{-1}$ ) and dry matter of the aerial part (DMAP, in $g$ plant ${ }^{-1}$ ), root length

$(\mathrm{RL}$, in $\mathrm{cm})$, fresh root matter (FRM, g plant $\left.{ }^{-1}\right)$ and dry root matter (DRM, in g plant $\left.{ }^{-1}\right)$ of four lettuce cultivars of

(Ceres, Gloriosa, Grandes Lagos and Rubinella), cultivated in the spring in 2016 and 2017, with shade netting.

\begin{tabular}{|c|c|c|c|c|c|c|}
\hline \multirow{2}{*}{ Cultivars } & \multicolumn{6}{|c|}{ Experiments 5 = season spring, year 2016, with shade netting } \\
\hline & NL & FLM & DLM & SL & SD & FSM \\
\hline Ceres & $16.75 \mathrm{a}^{*}$ & $176.87 \mathrm{~b}$ & $11.19 \mathrm{~b}$ & $5.55 \mathrm{a}$ & $2.08 \mathrm{~b}$ & $12.94 \mathrm{~b}$ \\
\hline Gloriosa & $18.25 \mathrm{a}$ & 345.57 a & $15.04 \mathrm{a}$ & $4.88 \mathrm{a}$ & $2.60 \mathrm{a}$ & $19.72 \mathrm{a}$ \\
\hline Grandes Lagos & $17.00 \mathrm{a}$ & $313.12 \mathrm{a}$ & $16.29 \mathrm{a}$ & $6.35 \mathrm{a}$ & $2.68 \mathrm{a}$ & $24.27 \mathrm{a}$ \\
\hline Rubinella & $14.00 \mathrm{a}$ & $109.61 \mathrm{c}$ & $5.22 \mathrm{c}$ & $5.33 \mathrm{a}$ & $1.48 \mathrm{c}$ & $7.17 \mathrm{c}$ \\
\hline Mean & 16.50 & 236.29 & 11.93 & 5.53 & 2.21 & 16.02 \\
\hline \multirow[t]{2}{*}{$\mathrm{CV}(\%)$} & 14.79 & 14.12 & 16.08 & 13.68 & 8.90 & 25.80 \\
\hline & DMS & FMAP & DMAP & RL & FRM & DRM \\
\hline Ceres & $0.71 \mathrm{~b}$ & $189.81 \mathrm{~b}$ & $11.90 \mathrm{~b}$ & $21.00 \mathrm{a}$ & $22.05 \mathrm{~b}$ & $1.16 \mathrm{a}$ \\
\hline Gloriosa & $0.97 \mathrm{a}$ & $365.29 \mathrm{a}$ & $16.01 \mathrm{a}$ & $22.30 \mathrm{a}$ & $32.21 \mathrm{a}$ & $1.50 \mathrm{a}$ \\
\hline Grandes Lagos & $1.17 \mathrm{a}$ & $337.40 \mathrm{a}$ & $17.47 \mathrm{a}$ & $22.90 \mathrm{a}$ & $48.39 \mathrm{a}$ & $1.83 \mathrm{a}$ \\
\hline Rubinella & $0.22 \mathrm{c}$ & $116.78 \mathrm{c}$ & $5.44 \mathrm{c}$ & $25.00 \mathrm{a}$ & $8.98 \mathrm{c}$ & $0.41 \mathrm{~b}$ \\
\hline Mean & 0.77 & 252.32 & 12.70 & 22.80 & 27.91 & 1.22 \\
\hline \multirow[t]{3}{*}{$\mathrm{CV}(\%)$} & 25.26 & 14.16 & 15.42 & 12.96 & 30.76 & 32.86 \\
\hline & \multicolumn{6}{|c|}{ Experiments 6 = season spring, year 2017, with shade netting } \\
\hline & NL & FLM & DLM & SL & $\mathrm{SD}$ & FSM \\
\hline Ceres & $15.00 \mathrm{~b}$ & $150.82 \mathrm{~b}$ & $7.53 \mathrm{c}$ & $4.78 \mathrm{~b}$ & $1.98 \mathrm{~b}$ & $9.15 \mathrm{~b}$ \\
\hline Gloriosa & $21.75 \mathrm{a}$ & $288.36 \mathrm{a}$ & $12.60 \mathrm{~b}$ & $3.58 \mathrm{c}$ & $2.10 \mathrm{a}$ & $9.44 \mathrm{~b}$ \\
\hline Grandes Lagos & $19.50 \mathrm{a}$ & $290.91 \mathrm{a}$ & $16.87 \mathrm{a}$ & $5.98 \mathrm{a}$ & $2.35 \mathrm{a}$ & $20.66 \mathrm{a}$ \\
\hline Rubinella & $15.50 \mathrm{~b}$ & $135.20 \mathrm{~b}$ & $5.90 \mathrm{~d}$ & $4.35 \mathrm{~b}$ & $1.75 \mathrm{~b}$ & $6.87 \mathrm{~b}$ \\
\hline Mean & 17.94 & 216.32 & 10.72 & 4.67 & 2.04 & 11.53 \\
\hline \multirow[t]{2}{*}{$\mathrm{CV}(\%)$} & 6.97 & 10.34 & 14.68 & 19.92 & 10.06 & 34.06 \\
\hline & DMS & FMAP & DMAP & RL & FRM & DRM \\
\hline Ceres & $0.40 \mathrm{c}$ & $159.97 \mathrm{~b}$ & $7.93 \mathrm{c}$ & $21.70 \mathrm{a}$ & $24.57 \mathrm{~b}$ & $2.17 \mathrm{a}$ \\
\hline Gloriosa & $0.58 \mathrm{~b}$ & $297.80 \mathrm{a}$ & $13.17 \mathrm{~b}$ & $23.90 \mathrm{a}$ & $31.10 \mathrm{a}$ & $2.17 \mathrm{a}$ \\
\hline Grandes Lagos & $1.19 \mathrm{a}$ & $311.57 \mathrm{a}$ & $18.06 \mathrm{a}$ & $22.48 \mathrm{a}$ & $43.20 \mathrm{a}$ & $2.87 \mathrm{a}$ \\
\hline Rubinella & $0.29 \mathrm{c}$ & $142.07 \mathrm{~b}$ & $6.20 \mathrm{~d}$ & $25.28 \mathrm{a}$ & $13.21 \mathrm{c}$ & $0.97 \mathrm{~b}$ \\
\hline Mean & 0.62 & 227.85 & 11.34 & 23.34 & 28.02 & 2.04 \\
\hline $\mathrm{CV}(\%)$ & 33.58 & 10.52 & 14.62 & 9.37 & 28.67 & 29.65 \\
\hline
\end{tabular}

* Means not followed by the same letters in the column (comparison of means between cultivars) differ to $5 \%$ of significance by the Scott-Knott test via bootstrap with 10,000 resampling.

In experiment 8 , the cultivar Crocantela presented superior performance for the traits, except for number of leaves (NL) (Table 5). The yield of fresh matter of the aerial part (FMAP) of the Crocantela cultivar was 52\% higher than that obtained in experiment 7 . This higher yield can be attributed to the minimum temperatures being between 14.5 and $22{ }^{\circ} \mathrm{C}$ (Figure 1), considered ideal for the crop (Maynard and Hochmuth, 2007). The cultivars Elisa, Rubinela and Vera presented inferior performance in relation to Crocantela, but similar to each other, except for the number of leaves (NL). According to Blind and Silva Filho (2015) in the summer conditions in the town of Presidente Figueiredo, State of Amazonas, Brazil, in soil cultivation with conventional beds, fresh matter of the aerial part of $290 \mathrm{~g} \mathrm{plant}^{-1}$ was obtained for the cultivar Tainá. Also, Resende et al. (2017), with cultivars of crisphead lettuce, in the Brazilian semi-arid region, obtained fresh matter of the aerial part and root matter between 150 and 400 g plant $^{-1}$ and stem length of 6.4 to 9.0 $\mathrm{cm}$, which were partially superior to that found in this study. 
Table 5. Number of leaves (NL), fresh matter (FLM, in $g$ plant ${ }^{-1}$ ) and dry matter (DLM, g plant ${ }^{-1}$ ) leaves, stem length (SL, in $\mathrm{cm}$ ), stem diameter (SD, in cm), fresh stem matter (FSM, in g plant ${ }^{-1}$ ) and dry stem matter (DSM, in $\mathrm{g} \mathrm{plant}^{-1}$ ), fresh matter of the aerial part (FMAP, in in $\mathrm{g} \mathrm{plant}^{-1}$ ) and dry matter of the aerial part (DMAP, in $\mathrm{g} \mathrm{plant}^{-1}$ ), root length

$(\mathrm{RL}$, in $\mathrm{cm})$, fresh root matter (FRM, g plant $\left.{ }^{-1}\right)$ and dry root matter (DRM, in $\mathrm{g} \mathrm{plant}^{-1}$ ) of four lettuce cultivars of (Crocantela, Elisa, Rubinella e Vera), cultivated in the summer in 2017 and 2018, without shade netting.

\begin{tabular}{|c|c|c|c|c|c|c|}
\hline \multirow{2}{*}{ Cultivars } & \multicolumn{6}{|c|}{ Experiments 7 = season summer, year 2017, without shade netting } \\
\hline & NL & FLM & DLM & SL & SD & FSM \\
\hline Crocantela & $12.75 \mathrm{c}^{*}$ & $95.28 \mathrm{a}$ & $3.28 \mathrm{~b}$ & $3.80 \mathrm{c}$ & $1.63 \mathrm{a}$ & $6.49 \mathrm{~b}$ \\
\hline Elisa & $21.75 \mathrm{a}$ & $67.41 \mathrm{~b}$ & $2.87 \mathrm{~b}$ & $3.83 \mathrm{c}$ & $1.65 \mathrm{a}$ & $7.29 \mathrm{~b}$ \\
\hline Rubinella & $15.25 \mathrm{~b}$ & $101.71 \mathrm{a}$ & $3.06 \mathrm{~b}$ & $9.28 \mathrm{a}$ & $1.43 \mathrm{a}$ & $11.61 \mathrm{a}$ \\
\hline Vera & $13.75 \mathrm{c}$ & $103.18 \mathrm{a}$ & $3.91 \mathrm{a}$ & $5.80 \mathrm{~b}$ & $1.73 \mathrm{a}$ & $10.25 \mathrm{a}$ \\
\hline Mean & 15.88 & 91.90 & 3.28 & 5.68 & 1.61 & 8.91 \\
\hline \multirow[t]{2}{*}{$\mathrm{CV}(\%)$} & 8.72 & 14.04 & 14.52 & 8.83 & 12.09 & 12.71 \\
\hline & DMS & FMAP & DMAP & RL & FRM & DRM \\
\hline Crocantela & $0.18 \mathrm{a}$ & $101.77 \mathrm{a}$ & $3.46 \mathrm{~b}$ & $18.50 \mathrm{a}$ & $18.23 \mathrm{a}$ & $0.96 \mathrm{a}$ \\
\hline Elisa & $0.22 \mathrm{a}$ & $74.70 \mathrm{~b}$ & $3.08 \mathrm{~b}$ & $16.20 \mathrm{~b}$ & $15.93 \mathrm{a}$ & $0.81 \mathrm{~b}$ \\
\hline Rubinella & $0.22 \mathrm{a}$ & $113.32 \mathrm{a}$ & $3.28 \mathrm{~b}$ & $20.03 \mathrm{a}$ & $16.22 \mathrm{a}$ & $0.68 \mathrm{~b}$ \\
\hline Vera & $0.24 \mathrm{a}$ & $113.44 \mathrm{a}$ & $4.15 \mathrm{a}$ & $18.93 \mathrm{a}$ & $21.89 \mathrm{a}$ & $1.12 \mathrm{a}$ \\
\hline Mean & 0.21 & 100.80 & 3.49 & 18.41 & 18.07 & 0.89 \\
\hline \multirow[t]{3}{*}{$\mathrm{CV}(\%)$} & 33.37 & 13.50 & 13.89 & 8.10 & 16.21 & 21.23 \\
\hline & \multicolumn{6}{|c|}{ Experiments $8=$ season summer, year 2018, without shade netting } \\
\hline & NL & FLM & DLM & SL & SD & FSM \\
\hline Crocantela & $18.75 \mathrm{~b}$ & $241.13 \mathrm{a}$ & $9.63 \mathrm{a}$ & $5.38 \mathrm{a}$ & $2.43 \mathrm{a}$ & $15.82 \mathrm{a}$ \\
\hline Elisa & $28.50 \mathrm{a}$ & $116.90 \mathrm{~b}$ & $6.94 \mathrm{~b}$ & $4.63 \mathrm{a}$ & $2.23 \mathrm{a}$ & $12.72 \mathrm{a}$ \\
\hline Rubinella & $15.50 \mathrm{c}$ & $127.47 \mathrm{~b}$ & $6.22 \mathrm{~b}$ & $5.70 \mathrm{a}$ & $1.80 \mathrm{~b}$ & $10.04 \mathrm{a}$ \\
\hline Vera & $13.25 \mathrm{~d}$ & $124.55 \mathrm{~b}$ & $6.96 \mathrm{~b}$ & $4.85 \mathrm{a}$ & $1.98 \mathrm{~b}$ & $9.75 \mathrm{a}$ \\
\hline Mean & 19.00 & 152.51 & 7.44 & 5.14 & 2.11 & 12.08 \\
\hline \multirow[t]{2}{*}{$\mathrm{CV}(\%)$} & 7.37 & 13.63 & 9.43 & 9.93 & 8.021 & 22.50 \\
\hline & DMS & FMAP & DMAP & $\mathrm{RL}$ & FRM & DRM \\
\hline Crocantela & $0.70 \mathrm{a}$ & $256.95 \mathrm{a}$ & $10.33 \mathrm{a}$ & $20.53 \mathrm{a}$ & $23.44 \mathrm{a}$ & $1.99 \mathrm{a}$ \\
\hline Elisa & $0.54 \mathrm{~b}$ & $129.63 \mathrm{~b}$ & $7.48 \mathrm{~b}$ & $19.00 \mathrm{a}$ & $19.65 \mathrm{~b}$ & $1.19 \mathrm{~b}$ \\
\hline Rubinella & $0.43 \mathrm{~b}$ & $137.51 \mathrm{~b}$ & $6.65 \mathrm{~b}$ & $18.18 \mathrm{a}$ & $9.04 \mathrm{c}$ & $1.25 \mathrm{~b}$ \\
\hline Vera & $0.43 \mathrm{~b}$ & $134.30 \mathrm{~b}$ & $7.39 \mathrm{~b}$ & $20.43 \mathrm{a}$ & $16.41 \mathrm{~b}$ & $0.95 \mathrm{~b}$ \\
\hline Mean & 0.52 & 164.60 & 7.96 & 19.53 & 17.13 & 1.35 \\
\hline $\mathrm{CV}(\%)$ & 17.36 & 14.12 & 9.64 & 8.49 & 16.52 & 22.11 \\
\hline
\end{tabular}

* Means not followed by the same letters in the column (comparison of means between cultivars) differ to $5 \%$ of significance by the Scott-Knott test via bootstrap with 10,000 resampling.

In the experiments carried out in the summer, with shade netting (experiments 9 and 10), the cultivars presented inferior performance when compared to experiment 9 (Table 6). This inferior performance may have been caused by daily maximum temperatures above $35^{\circ} \mathrm{C}$ (Figure 1) and daily solar radiation incidence exceeding $20 \mathrm{MJ} \mathrm{m}^{-2}$ for most of the period from transplant to harvest (Figure 2). In the experiment 9 the cultivar Vera presented superior performance when compared to other cultivars. Whereas, in experiment 10, the cultivar with the best performance was Crocantela. The cultivars Elisa, Rubinella and Vera had similar performance. During harvesting, in experiment 10, mean daily temperatures ranged from $21.5^{\circ} \mathrm{C}$ to $29.2{ }^{\circ} \mathrm{C}$ (Figure 1) and incident solar radiation from 6.67 $\mathrm{MJ} \mathrm{m}^{-2}$ to $28.97 \mathrm{MJ} \mathrm{m}^{-2}$ (Figure 2).

Experiments 7, 8, 9 and 10, carried out in the summer, different meteorological conditions were observed, being generally more favorable in 
Table 6. Number of leaves (NL), fresh matter (FLM, in g plant ${ }^{-1}$ ) and dry matter (DLM, g plant ${ }^{-1}$ ) leaves, stem length $(\mathrm{SL}$, in $\mathrm{cm})$, stem diameter (SD, in $\mathrm{cm})$, fresh stem matter (FSM, in g plant ${ }^{-1}$ ) and dry stem matter (DSM, in $\mathrm{g} \mathrm{plant}^{-1}$ ), fresh matter of the aerial part (FMAP, in in $\mathrm{g} \mathrm{plant}^{-1}$ ) and dry matter of the aerial part (DMAP, in $\mathrm{g}_{\text {plant }}{ }^{-1}$ ), root length

$(\mathrm{RL}$, in $\mathrm{cm})$, fresh root matter (FRM, g plant $\left.{ }^{-1}\right)$ and dry root matter (DRM, in g plant $\left.{ }^{-1}\right)$ of four lettuce cultivars of (Crocantela, Elisa, Rubinella e Vera), cultivated in the summer in 2017 and 2018, with shade netting.

\begin{tabular}{|c|c|c|c|c|c|c|}
\hline \multirow{2}{*}{ Cultivars } & \multicolumn{6}{|c|}{ Experiments $9=$ season summer, year 2017 , with shade netting } \\
\hline & NL & FLM & DLM & SL & $\mathrm{SD}$ & FSM \\
\hline Crocantela & $13.75 \mathrm{c}^{*}$ & $104.93 \mathrm{a}$ & $3.44 \mathrm{a}$ & $4.00 \mathrm{~b}$ & $1.63 \mathrm{~b}$ & $6.51 \mathrm{~b}$ \\
\hline Elisa & $24.00 \mathrm{a}$ & $88.69 \mathrm{a}$ & $3.87 \mathrm{a}$ & $4.23 \mathrm{~b}$ & $2.03 \mathrm{a}$ & $10.05 \mathrm{a}$ \\
\hline Rubinella & $12.50 \mathrm{c}$ & $61.80 \mathrm{~b}$ & $2.73 \mathrm{a}$ & $5.63 \mathrm{a}$ & $1.23 \mathrm{c}$ & $5.44 \mathrm{~b}$ \\
\hline Vera & $15.00 \mathrm{~b}$ & $94.06 \mathrm{a}$ & $3.95 \mathrm{a}$ & $5.43 \mathrm{a}$ & $1.55 \mathrm{~b}$ & $8.95 \mathrm{a}$ \\
\hline Mean & 16.31 & 87.37 & 3.50 & 4.82 & 1.61 & 7.74 \\
\hline \multirow[t]{2}{*}{$\mathrm{CV}(\%)$} & 9.65 & 16.61 & 16.72 & 9.96 & 9.72 & 21.51 \\
\hline & DMS & FMAP & DMAP & $\mathrm{RL}$ & FRM & DRM \\
\hline Crocantela & $0.20 \mathrm{a}$ & $111.44 \mathrm{a}$ & $3.63 \mathrm{a}$ & $16.58 \mathrm{a}$ & $15.90 \mathrm{a}$ & $0.91 \mathrm{a}$ \\
\hline Elisa & $0.26 \mathrm{a}$ & $98.75 \mathrm{a}$ & $4.13 \mathrm{a}$ & $16.33 \mathrm{a}$ & $18.27 \mathrm{a}$ & $0.73 \mathrm{a}$ \\
\hline Rubinella & $0.17 \mathrm{a}$ & $67.24 \mathrm{~b}$ & $2.91 \mathrm{a}$ & $17.70 \mathrm{a}$ & $11.33 \mathrm{~b}$ & $0.75 \mathrm{a}$ \\
\hline Vera & $0.30 \mathrm{a}$ & $103.01 \mathrm{a}$ & $4.24 \mathrm{a}$ & $18.13 \mathrm{a}$ & $16.41 \mathrm{a}$ & $0.90 \mathrm{a}$ \\
\hline Mean & 0.23 & 95.11 & 3.73 & 17.18 & 15.48 & 0.82 \\
\hline \multirow[t]{3}{*}{$\mathrm{CV}(\%)$} & 28.64 & 16.91 & 17.00 & 11.02 & 15.75 & 28.48 \\
\hline & \multicolumn{6}{|c|}{ Experiments $10=$ season summer, year 2017, with shade netting } \\
\hline & $\mathrm{NL}$ & FLM & DLM & $\mathrm{SL}$ & $\mathrm{SD}$ & FSM \\
\hline Crocantela & $18.25 \mathrm{~b}$ & $217.80 \mathrm{a}$ & $8.75 \mathrm{a}$ & $4.75 \mathrm{~b}$ & $2.30 \mathrm{a}$ & $14.74 \mathrm{a}$ \\
\hline Elisa & $31.00 \mathrm{a}$ & $127.06 \mathrm{~b}$ & $6.84 \mathrm{~b}$ & $4.58 \mathrm{~b}$ & $2.10 \mathrm{a}$ & $12.98 \mathrm{a}$ \\
\hline Rubinella & $15.25 \mathrm{c}$ & $111.31 \mathrm{~b}$ & $5.47 \mathrm{~b}$ & $5.80 \mathrm{a}$ & $1.65 \mathrm{a}$ & $8.79 a$ \\
\hline Vera & $14.50 \mathrm{c}$ & $117.71 \mathrm{~b}$ & $5.97 \mathrm{~b}$ & $4.28 \mathrm{~b}$ & $1.70 \mathrm{a}$ & $8.41 \mathrm{a}$ \\
\hline Mean & 19.75 & 143.47 & 6.76 & 4.85 & 1.94 & 11.23 \\
\hline \multirow[t]{2}{*}{$\mathrm{CV}(\%)$} & 12.27 & 19.37 & 15.11 & 13.84 & 19.25 & 28.92 \\
\hline & DMS & FMAP & DMAP & $\mathrm{RL}$ & FRM & DRM \\
\hline Crocantela & $0.68 \mathrm{a}$ & $232.53 \mathrm{a}$ & $9.43 \mathrm{a}$ & $21.38 \mathrm{a}$ & $24.39 \mathrm{a}$ & $2.18 \mathrm{a}$ \\
\hline Elisa & $0.56 \mathrm{a}$ & $140.04 \mathrm{~b}$ & $7.40 \mathrm{~b}$ & $20.43 \mathrm{a}$ & $21.14 \mathrm{a}$ & $1.23 \mathrm{~b}$ \\
\hline Rubinella & $0.43 \mathrm{~b}$ & $120.10 \mathrm{~b}$ & $5.90 \mathrm{~b}$ & $21.20 \mathrm{a}$ & $10.13 \mathrm{~b}$ & $0.92 \mathrm{~b}$ \\
\hline Vera & $0.38 \mathrm{~b}$ & $126.12 \mathrm{~b}$ & $6.35 \mathrm{~b}$ & $18.23 \mathrm{a}$ & $11.41 \mathrm{~b}$ & $0.91 \mathrm{~b}$ \\
\hline Mean & 0.51 & 154.70 & 7.27 & 20.31 & 16.77 & 1.31 \\
\hline $\mathrm{CV}(\%)$ & 23.45 & 19.88 & 15.46 & 9.98 & 33.80 & 25.11 \\
\hline
\end{tabular}

* Means not followed by the same letters in the column (comparison of means between cultivars) differ to $5 \%$ of significance by the Scott-Knott test via bootstrap with 10,000 resampling.

experiments 8 and 10, resulting better performance for the cultivars (Tables 5 and 6). The presence of shade netting within the sheltered environment did not reflect in better performance of the cultivars. Also, in the experiments in which the meteorological conditions were less favorable (experiments 7 and 9), the cultivar Vera stood out of from the others and in experiments in which the meteorological conditions were more favorable (experiments 8 and 10), Crocantela was the cultivar with better agronomic performance.
The use of shade netting in the spring and summer did not result in greater matter yield for the different organs or reduction in stem length. Thus, in these seasons, it can be inferred that the shade netting does not provide additional benefit the crop to the point of justifying the investment. One of the causes is the ventilation of the sheltered environment, due to keeping the sides permanently open. In addition, the low-density polyethylene used to cover the sheltered environment, with a transmissivity of $60 \%$, retains part of the solar 


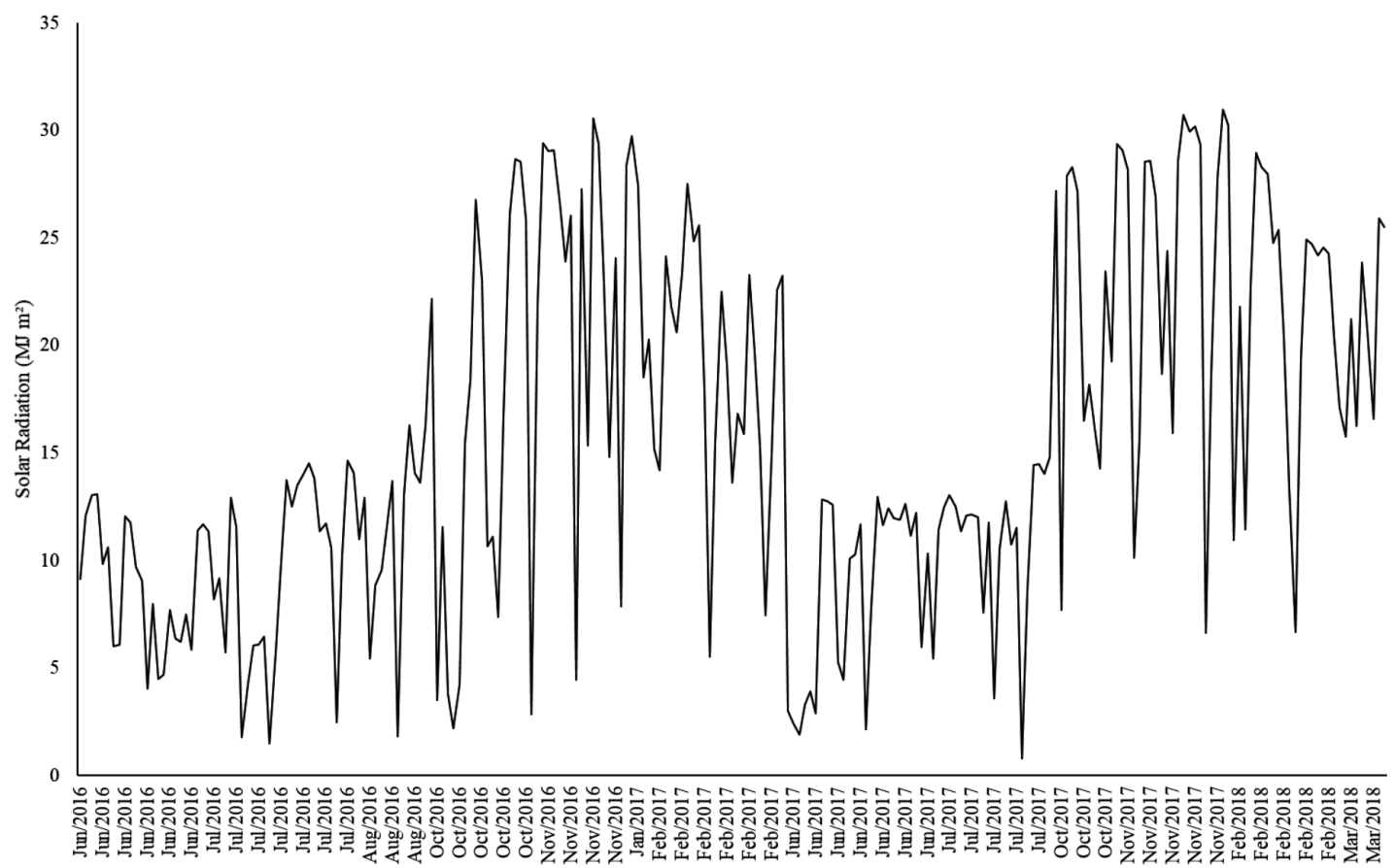

Figure 2. Daily incident solar radiation for the period from transplant to harvest, autumn-winter (June, July and August), spring (October and November) and summer (January, February and March), in Santa Maria, Rio Grande do Sul, Brazil.

radiation, reducing the effect of the shade netting. In contrast, in hydroponic cultivation, for the cultivar Mariane, in Tianguá, State of Ceará, Brazil, with Aw climate, during the winter the black shade netting reduced the temperature and increased the number of leaves (Sales et al., 2014). Also, in soil cultivation, without a sheltered enviroment environment, black and thermo-reflective netting are an alternative for lettuce production in a tropical climate (Diamante et al., 2013).

\section{Conclusion}

The cultivars Gloriosa (in autumn-winter), Grandes Lagos and Gloriosa (in spring) and Crocantela and Vera (in summer), presented greater matter yield and are the most suitable for cultivation in these seasons. The shade netting within the sheltered environment did not improve the performance of the cultivars and its use is not deemed necessary in the spring and summer.

\section{Literature Cited}

Alvares, C.A.; Stape, J.L.; Sentelhas, P.C.; Gonçalves, J.L.M.; Sparovek. G.

2013. Köppen's climate classification map for Brazil. Meteorologische Zeitschrift, 22 (6): 711-728.

Blat, S.F; Sanchez, S.V.; Araújo, J.A.C.; Bolonhezi, D. 2011. Performance of lettuce cultivars grown in two environments, in the NFT hydroponic system. Horticultura Brasileira 29 (1): 135-138.

Andriolo, J.L.

2017. Olericultura Geral. 3th ed. Editora UFSM. 93 p.

Blind, A.D.; Silva Filho, D.F.

2015. Productivity performance in cultivars of crisphead lettuce in the dry season of Central Amazonia. Bioscience Journal, 31 (2): 404-414.
CEAGESP.

2016. Companhia de Entrepostos e Armazéns Gerais de São Paulo. Available: http://www.ceagesp.gov.br/produtos/ alface-crespa/ Consulted.

Diamante, M.S.; Seabra, S.J.; Inagaki, A.M; Silva, M.B.; Dallacort, R.

2013. Production and resistance to bolting of loose-leaf lettuce grown in different environments. Revista Ciência Agronômica, 44 (1): 133-140.

FAO.

2013. Good Agricultural Practices for Greenhouse Vegetable Crops: Principles for Mediterranean Climate Areas. ITA, FAO. Rome, Italy. 616 p. 
Ferreira, D.F.

2014. Sisvar: a guide for its bootstrap procedures in multiple comparisons. Ciência e Agrotecnologia, 38 (2): 109-112.

Filgueira, F.A.R.

2008 Novo Manual de Olericultura: agrotecnologia moderna na produção e comercialização de hortaliças. 2th ed. Editora UFV. Brazil. 421 p.

Fu, W.; Li, P.; Wu, Y.

2012. Effects of different light intensities on chlorophyll fluorescence characteristics and yield in lettuce. Scientia Horticulturae, 135: 45-51.

Heldwein, A.B.; Buriol, G.A.; Streck, N.A.

2009. O clima de Santa Maria. Ciência e Ambiente, 38: 43-58.

Ilić, Z. S.; Fallik, E.

2017. Light quality manipulation improve vegetables quality at harvest and postharvest. A review. Environmental and Experimental Botany, 139: 79-90.

Lebada, A.; Delezalová, I.; Krístkova, E.; Kitner, M.;

Mieslerová, B.; Novotná, A.

2009. Wild Lactuca germplasm for lettuce breeding: current status, gaps and challenges. Euphytica, 170: 15-34.

Maynard, D.N.; Hochmuth, G.J.

2007. Knott's handbook or vegetable growers. 5 th ed. Editora John Wiley e Sons. 621 p.

Ntsoane, L.L.M.; Soundy, P.; Jifon, J.; Sivakumar, D.

2016. Variety-specific responses of lettuce grown under the different coloured shade nets on phytochemical quality after postharvest storage. Journal of the Science of Food and Agriculture, 91: 520-528.

Prela-Pantano, A.; Novo, M.C.S.S.; Trani, P.E.

2015. Performance of lettuce cultivars in the region of Americana, SP. Irriga, 20 (1): 92-104.
Resende, G.M.; Costa, N.D.; Yuri, J.E.; Mota, J.H.

2017. Adaptation of crispleaf lettuce genotypes at semi-arid conditions. Revista Brasileira de Agricultura Irrigada, 11 (1): 1145-1154.

Ryder, E.J.

2002. in Trends in new crops and new uses. Janick, J. \& Whipkey (eds), A. The new salad crop revolution. ASHS Press. pp. 408-412.

Sala, C.F.; Costa, C.P. da.

2012. Retrospective and trends of Brazilian lettuce crop. Horticultura Brasileira, 30 (2): 187-194.

Sales, A. de L.; Barbosa Filho, J.A.D; Barbosa, J.P.R.A.D.; Viana, T.V.A.; Freitas, C.A.S.

2014. Agricultural nets as undercover in hydroponic cultivation of lettuce. Ciência Rural, 44 (10): 1775-1760.

Santos, C.E.; Kist, B.B.; Carvalho, C.; Reetz, E. R.; Muller,

I.; Belig, R.R.; Poll, H.

2015. Anuário Brasileiro de hortaliças. Editora Gazeta. Brazil. 68 p.

Shahak, Y.

2014. Photoselective netting: an overview of the concept, $\mathrm{R} \& \mathrm{D}$ and practical implementation in agriculture. Acta Horticulturae, 1015: 155-162.

Taiz, L.; Zeiger, E.; Moller, I.M.; Murphy, A.

2017. Fisiologia e Desenvolvimento Vegetal. 6.ed. Artmed. Porto Alegre, Brazil. 858 p.

Yuri, J.E.; Resende, G.M.; Costa, N.D.; Gomes, A.S.

2017. Agronomic performance of crisphead lettuce genotypes at Sub-Middle São Francisco Valley. Horticultura Brasileira, 35 (2): 292-297.

Uno, Y.; Okubo, H.; Itoh, H.; Koyama, R.

2016. Reduction of leaf lettuce tipburn using an indicator cultivar. Scientia Horticulturae. 210: 14-18. 